\title{
Sphingosine Kinase 2
}

National Cancer Institute

\section{Source}

National Cancer Institute. Sphingosine Kinase 2. NCI Thesaurus. Code C128472.

Sphing osine kinase 2 (654 aa, $\sim 69 \mathrm{kDa}$ ) is encoded by the human SPHK2 gene. This protein is involved in phosphosphingolipid synthesis. 